\title{
Chitosan derivatives for gene transfer: effect of phosphorylcholine and diethylaminoethyl grafts on the in vitro transfection efficiency
}

Isadora Pfeifer Dalla Picola, Qin Shi, Júlio Cesar Fernandes, Maicon Segalla Petrônio, Aline Margarete Furuyama Lima, Vera Aparecida de Oliveira Tiera \& Marcio José Tiera

To cite this article: Isadora Pfeifer Dalla Picola, Qin Shi, Júlio Cesar Fernandes, Maicon Segalla Petrônio, Aline Margarete Furuyama Lima, Vera Aparecida de Oliveira Tiera \& Marcio José Tiera (2016) Chitosan derivatives for gene transfer: effect of phosphorylcholine and diethylaminoethyl grafts on the in vitro transfection efficiency, Journal of Biomaterials Science, Polymer Edition, 27:16, 1611-1630, DOI: 10.1080/09205063.2016.1225333

To link to this article: https://doi.org/10.1080/09205063.2016.1225333

+ View supplementary material ๘

Submit your article to this journal $\pi$
Accepted author version posted online: 17 Aug 2016. Published online: 31 Aug 2016.

Џ Article views: 93 


\title{
Chitosan derivatives for gene transfer: effect of phosphorylcholine and diethylaminoethyl grafts on the in vitro transfection efficiency
}

\author{
Isadora Pfeifer Dalla Picola ${ }^{a, b}$, Qin Shib ${ }^{b}$ Júlio Cesar Fernandes ${ }^{b}$, Maicon Segalla \\ Petrônioc, Aline Margarete Furuyama Lima ${ }^{c}$, Vera Aparecida de Oliveira Tiera ${ }^{c}$ and \\ Marcio José Tierac
}

\begin{abstract}
a'Department of Physics, IBILCE, São Paulo State University - UNESP, São José do Rio Preto, São Paulo, Brazil; bOrthopedic Research Laboratory, Hôpital du Sacré-Cœur de Montréal, Université de Montréal, Montréal, Canada; 'Department of Chemistry and Environmental Sciences, IBILCE, São Paulo State University - UNESP, São José do Rio Preto, São Paulo, Brazil
\end{abstract}

\begin{abstract}
The purpose of this work was to improve the functional properties of chitosan for gene transfer by inserting phosphorylcholine (PC) and diethylaminoethyl (DEAE) groups into the main chain. A series of derivatives containing increasing contents of DEAE and a fixed content of PC groups were synthesized and characterized, aiming to evaluate the effect of these groups on the nanoparticles' properties and the in vitro transfection efficiency. The derivatives were soluble at physiological $\mathrm{pH}$ levels and all derivatives were less cytotoxic than the control, the lipid lipofectamine. The obtained derivatives complexed pDNA into nanoparticles with smaller sizes and higher zeta potentials than plain chitosan. The in vitro transfection was performed with nanoparticles prepared at $\mathrm{pH} 6.3$ and 7.4 and the results showed that nanoparticles prepared with derivatives containing $20 \%$ of PC groups $\left(\mathrm{PC}_{18}-\mathrm{CH}\right)$ and high degrees of substitution by DEAE $\left(\mathrm{PC}_{20}-\mathrm{CH}-\mathrm{DEAE}{ }_{100}\right.$ $\mathrm{CH}-\mathrm{DEAE}{ }_{80} \mathrm{CH}-\mathrm{DEAE} \mathrm{1}_{100}$ ) displayed the better transfection efficiencies in HeLa cells, reaching relative values comparable to lipofectamine. The most effective derivative, $\mathrm{PC}_{18} \mathrm{CH}$, was selected for complexation with siRNA and its complexes demonstrated an in vitro knockdown efficiency highly dependent on the N/P ratio. Our combined results indicated that, by means of controlled modifications, the limitations of chitosan can be overcome to obtain more effective carriers based on chitosan, and the derivatives here studied hold potential for in vivo studies.
\end{abstract}

\section{ARTICLE HISTORY}

Received 16 June 2016

Accepted 15 August 2016

\section{KEYWORDS}

Chitosan; derivatives; phosphorylcholine; gene therapy; polyplexes; DNA; siRNA; nanoparticles

\section{Introduction}

Synthetic and natural polycations have gained a great importance in the non-viral gene therapy field, in particular, due to their properties of protecting nucleic acids from degradation

CONTACT Júlio Cesar Fernandes $\bigotimes$ julio.fernandes@videotron.ca; Marcio José Tiera mjt@ibilce.unesp.br

(4) The supplementary material for this paper is available online at http://dx.doi.org/10.1080/09205063.2016.1225333. 
and delivering them into the cytosol.[1,2] The potential applications of these polymers derive from structures containing protonable amino groups that drive the condensation of nucleic acids into nanoparticles.[3] However, the development of effective vectors based on cationic polymers has been challenged to achieve transfection efficiencies as high as those provided by viral vectors [2]; and in the last decades, many efforts have been made to improve biopolymer properties aiming at obtaining efficient non-viral vectors for gene delivery.[4,5]

Chitosan is one of the most studied biopolymers for this purpose, especially due to its ability to complex DNA and siRNA, which combined with other important properties such as biodegradability and low toxicity, have boosted the research on this polysaccharide.[6-10] However, as documented in the literature, the low transfection efficiency of polyplexes based on plain chitosan has limited its application.[11] The interaction pDNA-polycation is mainly driven by electrostatic interaction and leads to the formation of a complex that protects DNA from degradation. However, the cellular uptake and the delivery inside the cytosol are considered key steps; and several strategies have been adopted to overcome the limitations.[12,13]

Several studies indicate that polyplexes prepared from high molecular weight chitosan lead to a poor DNA release in living cells.[14] Moreover, the poor solubility at physiological $\mathrm{pH}[15,16]$ and easy recognition by the immune system are among the reported barriers.[17] A reported limitation of plain chitosan is that it relies on the $\mathrm{pKa}$ of the amino groups, which is around 6.2-6.4, resulting in a low ionization degree under physiological conditions, which in turn affects the colloidal stability of the nanoparticles.[13,16,18] Depending on the molecular weight, nanoparticles of chitosan at neutral $\mathrm{pH}$ may have sizes varying from $100 \mathrm{~nm}$ to micrometers,[14] affecting the transfection efficiency.[18,19] The control of molecular weight,[20] degrees of acetylation, [21] quaternization, [22] and the grafting of $\mathrm{pH}$-sensitive groups, [23,24] are among the strategies employed to improve the functional properties of chitosan and the delivery of pDNA into the cytosol. In general, modifications of chitosan structure with histidine,[23] PEI,[25,26] arginine, $[27,28]$ and poly(dimethylaminoethyl) methacrylate [29] may improve pDNA release into cytoplasm.

We have previously shown that phosphorylcholine-chitosan derivatives having low degrees of substitution (DS) (0.10-0.20) formed nanoparticles exhibiting enhanced colloidal stability.[30] The results were attributed to the high hydrophilicity of the PC group and to the higher $\mathrm{pKa}$ value $(-7.0)$ of the substituted amino groups.

The goal of this study was to evaluate the effect of insertion of phosphorylcholine (PC) and/or diethylaminoethyl (DEAE) groups on the in vitro transfection efficiencies of the nanoparticles. We hypothesized that the modification with these groups could be tuned to improve the intracellular release of DNA and the efficacy of gene transfer. Aiming to test this hypothesis, we select PC-CH derivative substituted with $20 \%$ of PC groups, which was also used for its in vitro ability to deliver siRNA-SSB. Derivatives based on PC-CH containing varied DS by diethylaminoethyl groups $\left(\mathrm{PC}_{20}-\mathrm{CH}-\mathrm{DEAE}_{\mathrm{y}}\right)$ were prepared and the in vitro transfection efficiency of nanoparticles synthesized at $\mathrm{pH} 6.3$ and 7.4 were tested and the results discussed, taking into account the DS. 


\section{Materials and methods}

\subsection{Materials}

Chitosan used as the starting material was purchased from Polymar, Brazil. The $s n$-glycero-3-phosphocholine was obtained from Bachem Chemical Co. Other reagents including 2-Chloro- $N, N$-diethylethylamine hydrochloride (DEAE), sodium periodate, sodium hydroxide, sodium acetate, acetic acid, sodium nitrite, were purchased from Aldrich Chemical Co. All solvents were reagent grade and used as received. Spectra/Pore membranes (Spectrum) were employed for dialysis. Plasmid DNA VR1412, encoding the $\beta$-galactosidase reporter gene with a CMV promoter and a backbone size of $8100 \mathrm{~kb}$ was obtained from Vical Inc. (San Diego, CA, U.S.A).[31] Sjogren syndrome antigen (SSB, GenBank accession number NM_009278)-targeted siRNA was provided by Merck and Co, Inc., (West Point, PA).[32] Water was deionized using a Milli-Q water purification system (Millipore).

\subsubsection{Amplification and purification of plasmid DNA VR1412}

The plasmid VR1412 was amplified with Escherichia coli bacteria and purified using the Qiagen Mega kit according to the manufacturer's instructions. The final plasmid was dissolved in water and analyzed by $0.8 \%$ agarose gel electrophoresis and UV-Visible spectrophotometer at $260-280 \mathrm{~nm}$.

\subsubsection{Instrumentation}

${ }^{1} \mathrm{H}-\mathrm{NMR}$ spectra were recorded on a Bruker ARX-400 $400 \mathrm{MHz}$ spectrometer, UV/ visible spectra were measured with a UV-Visible spectrophotometer/Shimadzu (Man-Tech Associates, Inc.), a Universal microplate reader-EL800 (Bio-Tek instruments, Inc.) was used for Elisa assay and cell viability measurements, and a Zetasizer-Nano series Nano-ZS90 (Malvern) was used for size and zeta potential measurements of the nanoparticles.

\subsection{Synthesis and characterization of chitosan derivatives}

\subsubsection{Synthesis and purification of polymers}

The chitosan was deacetylated and degraded as described earlier [5,30] and used as the starting material for the synthesis of all the PC-CH-DEAE and CH-DEAE derivatives. The first step of the procedure involves the reductive amination of PC glyceraldehyde,[33] with primary amines of the deacetylated chitosan used to prepare a PC-substituted chitosan (PC-CH) with a DS of -18 PC mol \% of glucosamine.[5,34] The PC-CH derivatives were further grafted with varied amounts of DEAE as described earlier.[35] The procedure is described as follows for the synthesis of $\mathrm{PC}_{18}-\mathrm{CH}-\mathrm{DEAE}_{38^{\circ}} 0.11 \mathrm{~g}$ of DEAE $(0.64 \mathrm{mM})$ was dissolved in a solution of $0.25 \mathrm{~g}$ of $\mathrm{PC}_{18}-\mathrm{CH}(-1.27 \mathrm{mM}$ of monosaccharide residues) in hydrochloric acid $(25 \mathrm{~mL}, 0.1 \mathrm{~mol} / \mathrm{L})$ resulting in a DEAE/ PC-CH molar ratio of 0.5 . The $\mathrm{pH}$ of the reaction mixture was adjusted to 8.0 by adding aqueous $\mathrm{NaOH}(2.0 \mathrm{M})$. The reaction mixture was stirred for $2 \mathrm{~h}$ at $65^{\circ} \mathrm{C}$ and the $\mathrm{pH}$ was controlled during the course of the reaction by adding $2.0 \mathrm{~mol} / \mathrm{L} \mathrm{NaOH}$ as required. The polymer was purified by dialysis (membrane of MWCO 12-14,000 g/mol) first against aqueous $\mathrm{NaOH}(0.05 \mathrm{M})$ for 1 day, and then against water for 3 days. The polymer PC-CH-DEAE was isolated by lyophilization (freeze drying). Other DEAE-substituted chitosans were prepared under identical conditions except for the initial $\mathrm{DEAE} / \mathrm{PC}_{18}-\mathrm{CH}$ molar ratios of $0.26,0.6,1.0$, and 2.0. 


\subsubsection{Gel permeation chromatography (GPC)}

GPC measurements were performed in a Shimadzu (LC-20) instrument equipped with a refractive index detector model RDI-10, using OHpak SB-803 HQ and OHpak SB-805 HQ columns (Shodex TM) with pullulan standards varying from 805 to $6.2 \mathrm{kDa}$. The mobile phase was acetic acid $(0.3 \mathrm{M}) /$ sodium acetate $(0.2 \mathrm{M}), \mathrm{pH} 4.5$, flow rate of $0.8 \mathrm{~mL} / \mathrm{min}$ at $35{ }^{\circ} \mathrm{C}$. Solutions for GPC analysis were prepared by dissolving the polymer in an acetic acid $(0.3 \mathrm{M})$ /sodium acetate $(0.2 \mathrm{M})$ buffer, to achieve a concentration between 0.5 and $1.0 \mathrm{mg} / \mathrm{mL}$. The polymer solutions were stirred for three days and filtered through a $0.45 \mu \mathrm{m}$ membrane before analysis.

\subsection{3. ${ }^{1} H N M R$ measurements}

${ }^{1} \mathrm{H}$ NMR spectra were recorded on a Bruker ARX-400 $400 \mathrm{MHz}$ spectrometer. Polymer solutions $(10 \mathrm{mg} / \mathrm{mL})$ were prepared in $\mathrm{D}_{2} \mathrm{O} / \mathrm{DCl}(100 / 1, \mathrm{v} / \mathrm{v})$ and their ${ }^{1} \mathrm{H}$ NMR spectra were recorded at $70{ }^{\circ} \mathrm{C}$.

\subsection{Preparation and characterization of polyplexes}

\subsubsection{Size, zeta potentials, transmission electron microscopy (TEM), and gel electrophoresis of polyplexes}

Stock solutions (1.0-1.5 mg/mL) of chitosan and its PC-CH-DEAE derivatives were prepared in an appropriate buffer (phosphate $25 \mathrm{mM}, \mathrm{pH} 6.3$ and ionic strength of $50 \mathrm{mM}$,

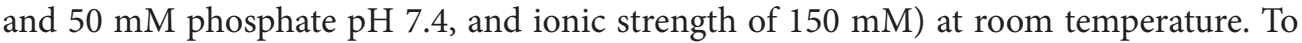
prepare chitosan-pDNA nanoparticles, a stock solution of VR 1412 plasmid DNA was added to test tubes containing $2 \mathrm{~mL}$ of the appropriate buffer to adjust the concentration of phosphate groups to $0.02 \mathrm{mM}$, as determined by the UV absorption at $260 \mathrm{~nm}$, using a molar extinction coefficient of $6600 \mathrm{M}^{-1} \mathrm{~cm}^{-1}$. Chitosan solutions were then injected into the tubes to obtain different $\mathrm{N} / \mathrm{P}$ ratios $(\mathrm{N}=$ amine groups from polycation/ $\mathrm{P}=$ phosphate groups from $\mathrm{pDNA}$ ) of the derivatives were used to prepare the nanoparticles solutions, which were vortexed briefly, and analyzed by dynamic light scattering after $30 \mathrm{~min}$ on a Zetasizer nano-ZS90, a He-Ne laser $(\lambda=633 \mathrm{~nm})$ and at $90^{\circ}$ scattering angle. The temperature was $25^{\circ} \mathrm{C}$ unless otherwise stated. The measurements were prepared in triplicate and average sizes were used. The chitosan-siRNA nanoparticles were prepared following the same procedure as described above, setting the concentration of phosphate groups of SSB-siRNA to $0.076 \mathrm{mM}$.

The morphology of the nanoparticles was examined by transmission electron microscopy. Ten microlitre of the complex solution was deposited on a formvar copper grid (carbon-coated copper grid, $200 \mathrm{mesh}$ ). The grids were allowed to dry for $30 \mathrm{~min}$, post-stained with a $2 \%$ solution of phosphotungstic acid, and the images recorded on an FEI Tecnai F20 HRTEM operating at $200 \mathrm{kV}$.

\subsubsection{Gel electrophoresis of polyplexes: integrity of DNA and protection of DNA against DNase I digestion}

Electrophoresis of pDNA and its nanoparticles with PC-CH-DEAE derivatives was performed with $0.8 \%$ agarose gel in Tris-Boric acid-EDTA buffer and a $1 \mathrm{~kb}$ DNA ladder from Invitrogen ${ }^{\mathrm{TM}}$. The plasmid concentration was adjusted to $0.6 \mu \mathrm{g} /$ well and for nanoparticles preparation the same pDNA concentration was fixed. Plasmid DNA integrity was checked 
by digestion of chitosan in the nanoparticles by chitosanase and lysozyme. The digestion was performed with $25 \mu \mathrm{L}$ of nanoparticles for different N/P ratios $(0.625 \mu \mathrm{g}$ of DNA) by adding $20 \mu \mathrm{L}$ of chitosanase at $5 \mathrm{U} / \mathrm{mL}$ and $5 \mu \mathrm{L}$ of lysozyme at $1000 \mathrm{U} / \mathrm{mL}$. The mixture was incubated at $37^{\circ} \mathrm{C}$ for $4 \mathrm{~h}$ and analyzed by electrophoresis. The protection against nuclease attack was assessed eletrophoretically on a $0.8 \%$ gel agarose following the procedure described by Douglas et al. 2006. Naked DNA $(2.0 \mu \mathrm{g})$ and $\mathrm{PC}_{18}-\mathrm{CH} / \mathrm{pDNA}$ nanoparticles at $\mathrm{N} / \mathrm{P}$ ratio 2.0 (containing $2.0 \mu \mathrm{g}$ of DNA in $40 \mu \mathrm{L}$ of acetate buffer, $\mathrm{pH}$ 5) were treated with 2.5 and $5 \mathrm{U}$ of DNaseI and incubated for $30 \mathrm{~min}$ at $37^{\circ} \mathrm{C}$. The reactions were stopped inactivating the DNaseI by heating the samples at $60^{\circ} \mathrm{C}$ for $15 \mathrm{~min}$ in the presence of $25 \mathrm{mM}$ EDTA. Half of the samples $(20 \mu \mathrm{L})$ were digested with $16 \mu \mathrm{L}$ of chitosanase $(5 \mathrm{U} / \mathrm{mL})$ and $4 \mu \mathrm{L}$ of lysozyme $(1000 \mathrm{U} / \mathrm{mL})$ for $4 \mathrm{~h}$ at $37^{\circ} \mathrm{C}$. After treatments, the samples were analyzed by electrophoresis at $170 \mathrm{~V}$ for $30 \mathrm{~min}$.

\subsection{Cell viability and transfection efficiency}

\subsubsection{Cytotoxicity assay}

Hela cervical carcinoma (FR-positive) cells were obtained from America Type Culture cell Collection (Rockville, MD, U.S.A). Cells were seeded on 96-well plates at a density of 10,000 cells/well and grown in DMEM medium supplemented with fetal bovine serum (FBS) and 1\% penicillin-streptomycin (PS). Next day, the medium was removed and $50 \mu \mathrm{L}$ of free plasmid DNA $(0.25 \mu \mathrm{g} /$ well $)$ or siRNA $(0.5 \mu \mathrm{g} /$ well $)$ or their nanoparticles were added to the cells with $50 \mu \mathrm{L}$ of complete medium and incubated for $24 \mathrm{~h}$. The cell viability was evaluated by CellTiter $96^{\circledR}$ Aqueous Non-Radioactive Cell Proliferation Assay (Promega Corporation) composed of 3-(4,5-dimethylthiazol-2-yl)-5-(3-carboxymethoxyphenyl)-2-(4-sulfophenyl)-2H-tetrazolium, inner salt (MTS), and phenazine methosulfate. MTS is bioreduced by viable cells to formazan soluble in tissue culture medium. Absorbance was measured at $490 \mathrm{~nm}$ with an EL800 universal microplate reader (Molecular Devices Corp., Menlo Park, CA, U.S.A). The percentage of cell viability was calculated by setting the control cells without nanoparticles as $100 \%$.

\subsubsection{Cell culture, transfection protocol with VR 1412 plasmid and determination of the transfection efficiencies}

Hela cells were seeded $24 \mathrm{~h}$ prior transfection on 24 -well plates at a density of 50,000 cells/ well in DMEM medium with 10\% FBS and 1\% PS. On the day of transfection, the culture medium was replaced by $200 \mu \mathrm{L}$ of free DNA or by $200 \mu \mathrm{L}$ of poliplexes $(5 \mu \mathrm{g}$ of DNA/ well) and added $200 \mu \mathrm{L}$ of new DMEM medium. After $4 \mathrm{~h}$ of incubation at $37^{\circ} \mathrm{C}$, the cells received $1 \mathrm{~mL}$ of completed medium with $10 \%$ FBS and $1 \%$ PS and incubated for $24 \mathrm{~h}$. The medium was removed and new medium was added. After $72 \mathrm{~h}$ the medium was removed and the cells were washed with cold PBS buffer. The transfection efficiency was evaluated using a $\beta$-gal Elisa kit (ROCHE) and BCA assay according to the manufacturer's instructions.

\subsubsection{Cell transfection protocol and evaluation of transfection efficiency with SiRNA-SSB}

Cell culture and transfection protocol with siRNA-SSB was carried out as previously described with minor modifications ${ }^{35}$. HeLa cells were seeded in 6-well plates at a density of $10^{5}$ cell/well with $3 \mathrm{~mL}$ of DMEN supplemented with $10 \%$ of FBS and $1 \%$ of PS in 
Table 1. Properties of chitosan and its derivatives.

\begin{tabular}{|c|c|c|c|c|c|}
\hline Derivative & $\mathrm{Mw}\left(\mathrm{gmol}^{-1}\right)$ & $\mathrm{Mw} / \mathrm{Mn}$ & $\mathrm{DS}_{\mathrm{PC}} \mathrm{Mol}(\%)$ & $\mathrm{DS}_{\mathrm{DEAE}} \mathrm{Mol}(\%)$ & $\mathrm{DS}_{\text {DEAEQ }} \mathrm{Mol}(\%)$ \\
\hline $\mathrm{CH}^{*}$ & 29.0 & 1.6 & - & - & \\
\hline $\mathrm{PC}_{18}-\mathrm{CH}$ & 41.0 & 3.3 & 18 & - & \\
\hline $\mathrm{PC}_{18}^{18}-\mathrm{CH}-\mathrm{DEAE} \mathrm{E}_{22}$ & 29.0 & 2.3 & 18 & 22 & \\
\hline $\mathrm{PC}_{18}^{18}-\mathrm{CH}-\mathrm{DEAE} \mathrm{E}_{38}^{22}$ & 33.0 & 2.3 & 18 & 31.7 & 6.3 \\
\hline $\mathrm{PC}_{18}^{18}-\mathrm{CH}-\mathrm{DEAE} \mathrm{E}_{44}^{38}$ & 32.0 & 2.4 & 18 & 44 & \\
\hline $\mathrm{PC}_{20}^{18}-\mathrm{CH}$ & 242 & 6.5 & 21.5 & - & \\
\hline $\mathrm{PC}_{20}^{20}-\mathrm{CH}-\mathrm{DEAE}{ }_{100}$ & 134 & 3.7 & 22 & 109 & 33.9 \\
\hline $\mathrm{CH}-\mathrm{DEAE} \mathrm{E}_{80}$ & 234 & 4.4 & - & 60.1 & 15.3 \\
\hline CH-DEAE & 197 & 2.7 & - & 92.5 & 15.8 \\
\hline
\end{tabular}

Notes. Mw: weight average molecular weight $\left(\mathrm{g} \mathrm{mol}^{-1}\right) ; \mathrm{DS}_{\mathrm{PC}}$ : Degree of Substitution by PC (\%); $\mathrm{DS}_{\mathrm{DEAE}}$ : Degree of Substitution by DEAE (\%); $\mathrm{D}_{\text {SDEAEO }}$ Quaternized DEAE groups (\%).

* Starting chitosan (DDA 99\%) for preparation of $\mathrm{PC}_{18}-\mathrm{CH}$ and $\mathrm{PC}_{18}-\mathrm{CH}-\mathrm{DEAEx}$.

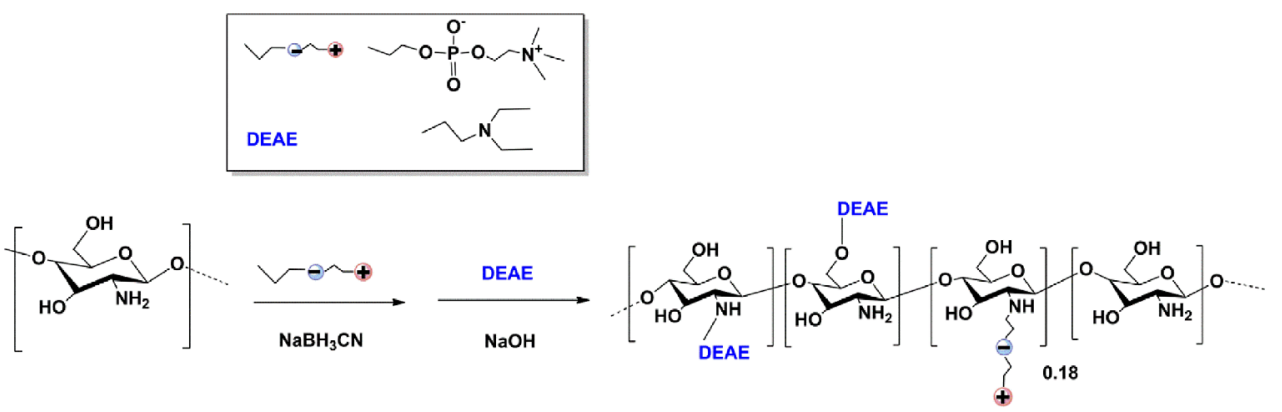

Figure 1. Scheme for the synthesis of the phosphorylcholine-DEAE derivatives of chitosan $\mathrm{PC}_{18}-\mathrm{CH}_{-} \mathrm{DEAE} \mathrm{X}_{\mathrm{X}}$.

atmosphere of $5 \% \mathrm{CO}_{2}$ and $95 \%$ of $\mathrm{O}_{2}$ at $37^{\circ} \mathrm{C}$. After $24 \mathrm{~h}$, the wells were washed three times with fresh DMEN, without FBS and PS, and treated with $500 \mu \mathrm{L}$ of DMEN and $500 \mu \mathrm{L}$ of polyplexes containing an equivalent amount of $5 \mu \mathrm{g}$ of siRNA-SSB. The cells were incubated for $4 \mathrm{~h}$ at $37^{\circ} \mathrm{C}$ and were treated with $2 \mathrm{~mL}$ of DMEN supplemented with $10 \%$ of FBS and $1 \%$ of PS and incubated for $24 \mathrm{~h}$. On the following day, the medium was replaced with $3 \mathrm{~mL}$ of DMEN with supplements. After $48 \mathrm{~h}$, the wells were washed three times with PBS and the cells were treated with TRIzol for purification of RNA following the manufacturer's instructions (Ambion/RNA by Life technologies). The transfection efficiencies were evaluated as previously described in Fernandes et al. [32].

\section{Results and discussion}

\subsection{Synthesis and structure analysis}

All the molecular properties of deacetylated chitosan and its PC-DEAE derivatives are presented in Table 1. The degree of deacetylation of the deacetylated sample was $99.0 \mathrm{~mol} \%$. This value was obtained from the areas of the doublet at $\delta 5.5 \mathrm{ppm}$, due to the resonance of the anomeric proton $\left(\mathrm{H}_{1}\right)$ and of the singlet at $\delta 2.6 \mathrm{ppm}$ attributed to the acetamido methyl protons (Figure 2). The deacetylated chitosan was first treated with PC-glyceraldehyde, and second, with DEAE (Figure 1). The first step was carried out to obtain a degree of 
(a)

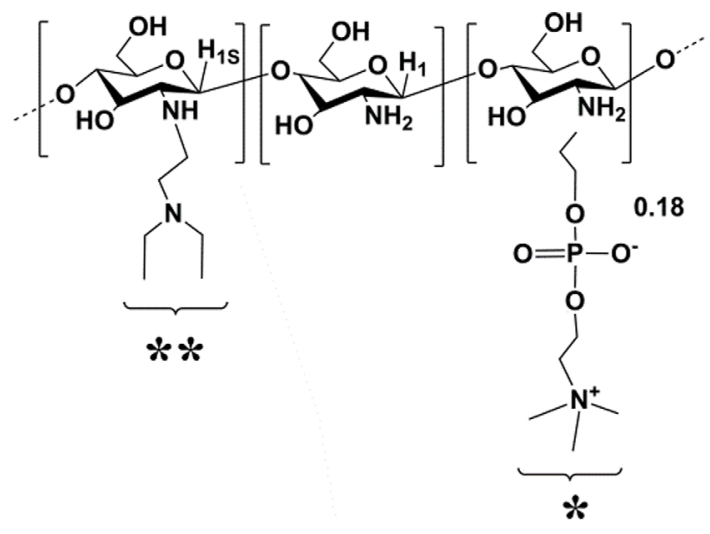

(b)


Figure 2. (a) General structure of PC-CH-DEAE derivatives and (b) ${ }^{1} \mathrm{H}-\mathrm{NMR}$ of chitosan and its phosphorylcholine and DEAE derivatives.

substitution of $20 \%$ of PC groups, which was shown to be an appropriate composition to obtain nanoparticles having an improved colloidal stability.[30] The degree of substitution by PC groups was determined as previously described [5] by comparing the signals due to 
the anomeric protons of PC-substituted and unsubstituted glucosamine residues, $\mathrm{H}_{1}$ and $\mathrm{H}_{1 \mathrm{~s}}$ (Figure 2), at $\delta 5.31$ and $5.44 \mathrm{ppm}$, respectively, using Equation (1):

$$
\mathrm{DS}_{\mathrm{PC}}=\frac{I_{H_{1 s}}}{I_{H_{1}}+I_{H_{1 s}}}
$$

Moreover, the successful incorporation of PC groups is evidenced by the singlet at $\delta 3.61 \mathrm{ppm}$, attributed to the resonance of the trimethylammonium protons of the PC moiety. The DS by DEAE groups was determined as reported previously ${ }^{33}$ from the areas $\left(\mathrm{I}_{\mathrm{CH} 3}\right)$ of the signal at $\delta 1.71 \mathrm{ppm}$ attributed to the resonance of the two methyl groups $\left(-\mathrm{N}\left(\mathrm{CH}_{2}-\mathrm{CH}_{3}\right)_{2}\right.$, Figure 2) compared to the area of the signals due to the anomeric protons of substituted and unsubstituted glucosamine residues $\left(\mathrm{H}_{1 \mathrm{~s}}\right.$ and $\left.\mathrm{H}_{1}\right)$, respectively, using Equation (2).

$$
\mathrm{DS}_{\mathrm{DEAE}}=\frac{I_{\mathrm{CH}_{3}} / 6}{\left(I_{H_{1}}+I_{H_{1 S}}\right)}
$$

The average molecular weight (Mw) determined from GPC analysis (Figure S1, Supplementary material) confirmed that the molecular mass of the derivatives were not significantly affected when compared to the starting chitosan $(29,000 \mathrm{~g} / \mathrm{mol})(\mathrm{Mw} / \mathrm{Mn}=1.60)$. Although some degradation may take place during the 2 nd step of the reaction, $\mathrm{Mw}$ for $\mathrm{PC}_{\mathrm{x}}-\mathrm{CH}-\mathrm{DEAE}$ derivatives remained around $30 \mathrm{kDa}$ (Table 1). The obtained $\mathrm{Mw}$ values may be rationalized, taking into account that the attaching of these groups may induce conformational changes affecting the retention time; moreover, the molecular weight distribution is also affected by the extensive purification by dialysis.

\subsection{Size, zeta potential and shape of polyplexes}

The size and zeta potential of the polyplexes were analyzed by dynamic light scattering and the strength of interaction between the pDNA and the derivatives was evaluated by gel agarose electrophoresis. The effects of PC and DEAE groups on polyplexes properties were compared to deacetylated chitosan. All derivatives were able to form polyplexes with VR1412 plasmid (pDNA) at both pH 6.3 and 7.4 (Figures 3 and S3(b) Supplementary Material) and derivatives are complexed more efficiently with pDNA than chitosan. However, as can be seen from Figure 3, the sizes were greatly dependent on N/P ratios. At $\mathrm{pH}$ 6.3, deacetylated chitosan formed polyplexes ranging from 400 to $500 \mathrm{~nm}$, even at N/P ratios as high as 30 (Figure 3(a)). The results are similar to those reported earlier for chitosan having similar Mw [36] and they can be credited to the low ionization degree of chitosan at this $\mathrm{pH}$ and accordingly to the lower zeta potentials of the $\mathrm{CH}$ polyplexes (Figure 3(b)). On the contrary, the sizes of the polyplexes obtained with $\mathrm{PC}_{18}-\mathrm{CH}$ and $\mathrm{PC}_{18}-\mathrm{CH}-\mathrm{DEAE}_{\mathrm{x}}$ derivatives decreased abruptly with $\mathrm{N} / \mathrm{P}$ ratio reaching diameters around of $100 \mathrm{~nm}$ for $\mathrm{N} / \mathrm{P}>5.0$. These results correlated well with the zeta potential measurements and at N/P ratio 2.0 polyplexes prepared with all derivatives exhibited higher zeta potentials than those provided by $\mathrm{CH}$ (Figure 3(b)).

The sizes of $\mathrm{PC}_{18}-\mathrm{CH}-\mathrm{DNA}$ polyplexes at N/P ratios ranging from 2 to 30 exhibited hydrodynamic diameters (Dhs) almost threefolds smaller than those prepared with $\mathrm{CH}$, 

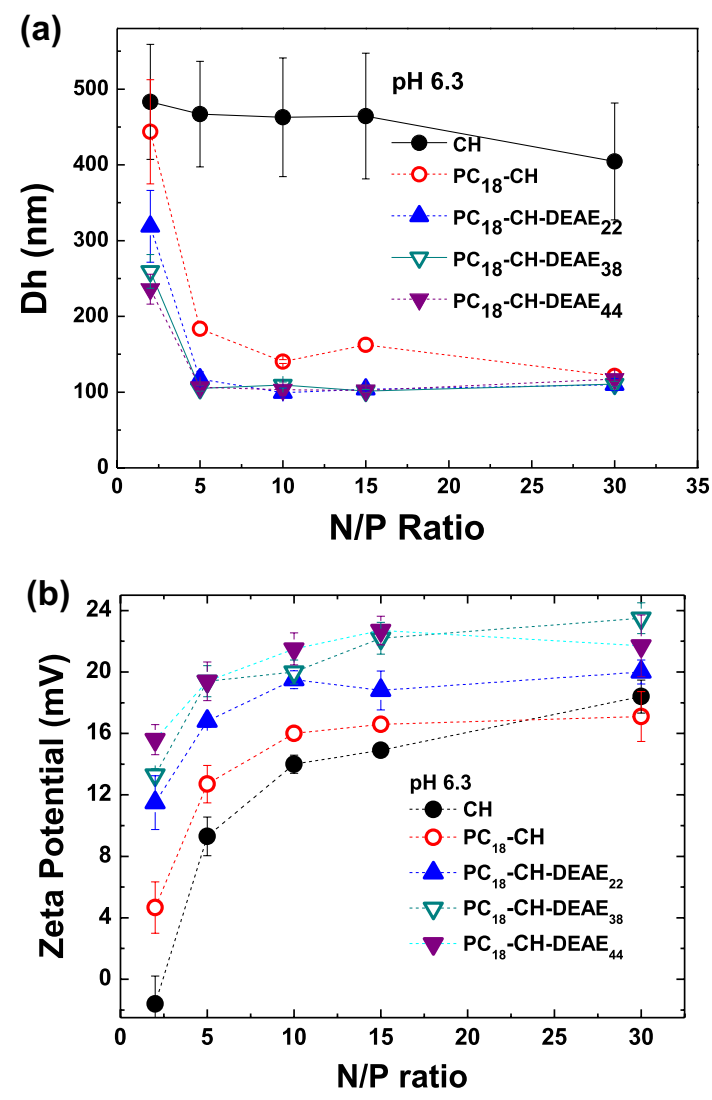

(c)

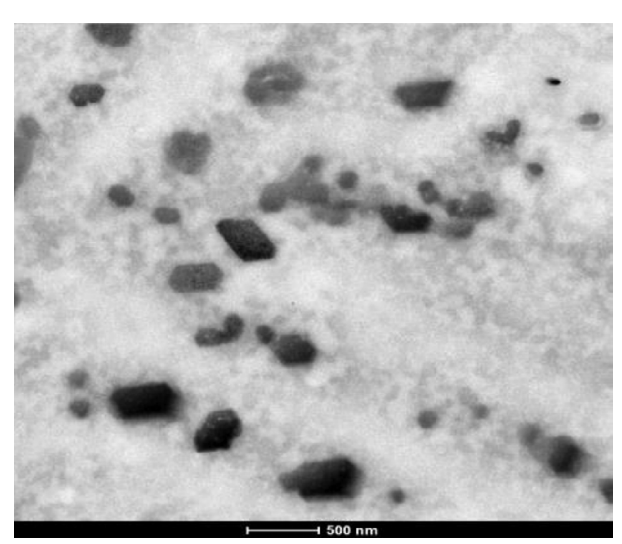

Figure 3. (a) Polyplexes sizes and (b) zeta potentials at $\mathrm{pH} 6.3$ for increasing $\mathrm{N} / \mathrm{P}$ ratios of $\bullet \mathrm{CH}, \mathrm{O}-\mathrm{PC}_{18}$ -


polyplexes prepared at N/P ratio 10 .

which can be credited to both, the pKa of the PC-substituted amino group [5] and the hydrophilic nature of the PC group. Moreover, on contrary of $\mathrm{CH}-\mathrm{DNA}$ polyplexes that are more prone to aggregation,[37] $\mathrm{PC}_{18} \mathrm{CH}-\mathrm{DNA}$ polyplexes exhibited no change in size following incubation in buffered solution over a period of two hours, confirming the stabilizing effect 
(a) $\mathrm{PC}_{18}-\mathrm{CH}$

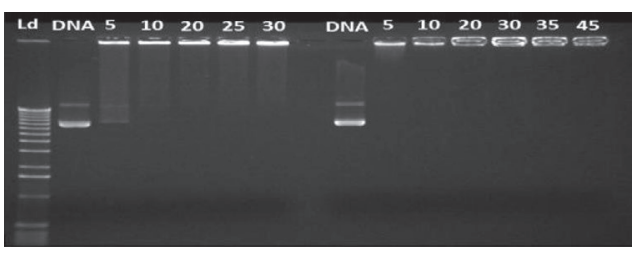

(c) $\mathrm{PC}_{18}-\mathrm{CH}$

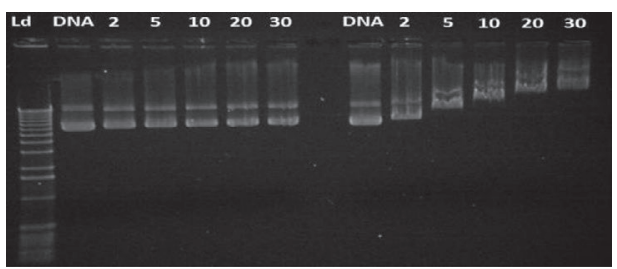

(b) $\mathrm{PC}_{18}$-CH-DEAE $38 \quad$ PC $_{18}-$ CHDEAE $_{44}$

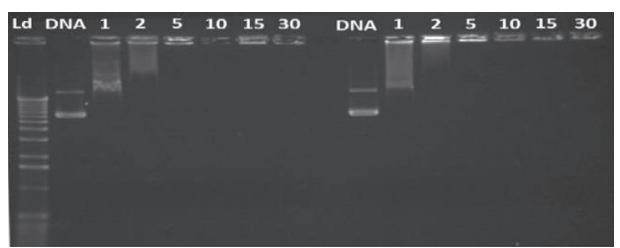

(d) $\mathrm{PC}_{18}-\mathrm{CH}$ : DNase I assay protection

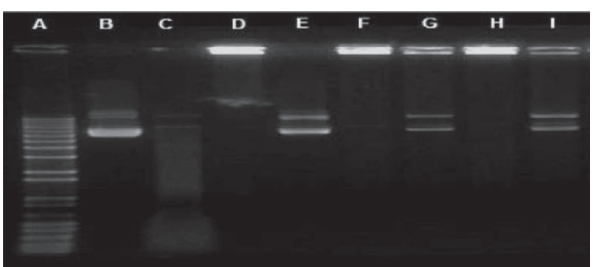

Figure 4. Electrophoresis of nanoparticles prepared with plasmid VR1412 and (a) $\mathrm{PC}_{18}-\mathrm{CH}$ and $\mathrm{PC}_{18}-\mathrm{CH}-\mathrm{DEAE} \mathrm{E}_{22^{\prime}}$ (b) $\mathrm{PC}_{18}-\mathrm{CH}_{-}-\mathrm{DEAE}_{38}$ and $\mathrm{PC}_{18}-\mathrm{CHDEAE}_{44}$ at $\mathrm{pH}$ 6.3. (c) Electrophoresis of nanoparticles prepared with $\mathrm{PC}_{18}-\mathrm{CH}$ and $\mathrm{PC}_{18}-\mathrm{CH}-\mathrm{DEAE} \mathrm{E}_{22}$ after digestion with lysozyme and chitosanase. The $\mathrm{N} / \mathrm{P}$ ratios are indicated at the top of the wells. (d) Electrophoresis of pDNA- $\mathrm{PC}_{18}-\mathrm{CH}$ nanoparticles prepared at N/P 10 and pH 6.3 after incubation with DNasel : A: Ladder; B: pDNA; C: pDNA + $2.5 \mathrm{u}$ of DNasel; D: $\mathrm{PC}_{18}-\mathrm{CH} / \mathrm{pDNA}$ nanoparticles at N/P 10; $\mathrm{E}: \mathrm{PC}_{18}-\mathrm{CH} / \mathrm{pDNA}$ nanoparticles + lysozyme and chitosanase, $\mathrm{F}: \mathrm{PC}_{18}-\mathrm{CH} / \mathrm{pDNA}$ nanoparticles + 2.5u DNasel; $\mathrm{G}: \mathrm{PC}_{18}-\mathrm{CH} / \mathrm{pDNA}$ nanoparticles $+2.5 \mathrm{u}$ DNasel + chitosanase + lysozyme; $\mathrm{H}: \mathrm{PC}_{18}-\mathrm{CH} / \mathrm{pDNA}$ nanoparticles + $5 \mathrm{u}$ DNasel, I: $\mathrm{PC}_{18}-\mathrm{CH} / \mathrm{pDNA}$ nanoparticles + 5u DNasel + chitosanase + lysozyme.

of PC groups (Figure S3(c), Supplementary material). The zeta potentials increased with increasing DEAE content and this trend can be explained based on the chitosan substitution, which gives rise to secondary and tertiary amino groups having $\mathrm{pKa}$ values higher than that of plain chitosan. The secondary amino groups of the PC-CH derivative has a pKa value around 7.0,[5] and amino groups provided by DEAE are positively charged even at physiological $\mathrm{pH} .[35]$

At $\mathrm{pH} 7.4$, all derivatives formed nanosized polyplexes ranging from 140 to $600 \mathrm{~nm}$, depending on $\mathrm{N} / \mathrm{P}$ ratio and $\mathrm{DS}_{\mathrm{DEAE}}$. Moreover, as can be seen from Figure S3(a) (Supplementary Material), both PC-CH derivatives $\left(\mathrm{PC}_{18}-\mathrm{CH}, \mathrm{Mw} 29 \mathrm{kDa}\right.$, and $\mathrm{PC}_{20}-\mathrm{CH}$, Mw $242 \mathrm{kDa}$ ), even when exhibiting the lower zeta potentials (ranging of -5 to $5 \mathrm{mV}$ ), formed polyplexes around 300-400 nm, indicating that PC groups may help the formation of more hydrated surfaces thus decreasing the aggregation process. However, the derivative having higher $\mathrm{Mw} \mathrm{PC}_{20}-\mathrm{CH}$ interacts strongly with pDNA and accordingly, at N/P > 5.0 leads to formation of particles with Dhs around $170 \mathrm{~nm}$ (Figure S3(a)).

The derivatives with increasing DEAE contents $\left(\mathrm{PC}_{18}-\mathrm{CH}-\mathrm{DEAE}_{44}\right.$ and $\mathrm{PC}_{20}-\mathrm{CH}$ $\mathrm{DEAE}_{100}$ ), formed particles with $\mathrm{D}_{\mathrm{h}}$ smaller than $300 \mathrm{~nm}$ (Figure S3(a), Supplementary Material) and positive zeta potentials $(>+6 \mathrm{mV}$ ) at N/P 10 (Figure S3(b)). Moreover, chitosan derivatives modified only with DEAE, CH-DEAE ${ }_{80}$, and CH-DEAE ${ }_{100}$ interact more strongly with pDNA and their complexes gave an average Dhs of around 200-230 nm with zeta potentials of +10 and $+15 \mathrm{mV}$, respectively (Figure S4(a) and (b) Supplementary Material). Micrographs of polyplexes obtained from TEM measurements showed roughly spherical shapes of broad sizes distribution varying from 70 to $300 \mathrm{~nm}$. A similar pattern 
was also observed for TEM measurements from $\mathrm{CH}_{-} \mathrm{DEAE}_{100}$ polyplexes. However, more uniform spherical shapes were observed (Figure S4(c)), which could be credited to its higher $\mathrm{Mw}(234 \mathrm{kDa})$, providing a stronger interaction with pDNA and more uniform spherical polyplexes.

\subsection{Gel electrophoresis}

The stability of the polyplexes and the integrity of pDNA were evaluated by gel electrophoresis and are shown in Figure 4 at $\mathrm{pH}$ 6.3. The strength of interaction increases with DEAE content and particles formed by $\mathrm{PC}_{18}-\mathrm{CH}$ and $\mathrm{PC}_{18}-\mathrm{CH}-\mathrm{DEAE}_{22}$ (Figure 4(a)) did not release the $\mathrm{pDNA}$ for $\mathrm{N} / \mathrm{P}$ ratios higher than 5 , while polyplexes of $\mathrm{PC}_{18}-\mathrm{CH}-\mathrm{DEAE}_{38}$ and $\mathrm{PC}_{18}-\mathrm{CH}-\mathrm{DEAE}_{44}$ retained the $\mathrm{pDNA}$ at $\mathrm{N} / \mathrm{P}$ ratio 2 (Figure $4(\mathrm{~b})$ ), which indicates an efficient binding with $\mathrm{pDNA}$ at this $\mathrm{pH}$.

At $\mathrm{pH} 7.4, \mathrm{PC}_{18}-\mathrm{CH}$ was efficient in retaining the pDNA into the well for $\mathrm{N} / \mathrm{P}>10$ (Supplementary Material, Figure S5(a)). Overall, the derivatives having higher DEAE contents and higher $\mathrm{Mw}\left(\mathrm{PC}_{18}-\mathrm{CH}-\mathrm{DEAE}_{44}, \mathrm{PC}_{20}-\mathrm{CH}\right.$ and $\mathrm{PC}_{20}-\mathrm{CH}-\mathrm{DEAE}{ }_{100}$, respectively) provided more stable polyplexes and did not release $\mathrm{pDNA}$ over the N/P range studied, i.e. from N/P 2 to 30 (Supplementary Material, Figures S5(b)-(d)). The DEAE content reinforces the pDNA-polycation interaction and the results obtained follow the same trend of previous studies and denote the importance of controlling $\mathrm{Mw}$ and N/P ratio to obtain stable nanoparticles to protect pDNA from degradation.[37-39]

Although the retaining of pDNA in the wells is observed for all derivatives, the condensation process must not affect the pDNA integrity and functionality, which was examined by digestion of the nanoparticles. Figure 4(c) shows the release of pDNA after digestion with chitosanase of the NPs obtained with $\mathrm{PC}_{18}-\mathrm{CH}$ and $\mathrm{PC}_{18}-\mathrm{CH}-\mathrm{DEAE} \mathrm{E}_{22}$, respectively. The integrity of pDNA after digestion was clearly confirmed for the nanoparticles prepared with these two derivatives, at all $\mathrm{N} / \mathrm{P}$ ratios $\left(2,5,10,20\right.$, and 30). For $\mathrm{PC}_{18}-\mathrm{CH}-\mathrm{DEAE}_{22}$, pDNA was not totally released from the digestion at $\mathrm{N} / \mathrm{P}$ ratios higher than 2 , which is probably due to a slower degradation process, partially credited to the insertion of DEAE groups. This interpretation was supported by the electrophoresis experiment performed with polyplexes of the most substituted derivative, which was not degraded by chitosanase and lysozyme.

The protection of the pDNA against degradation by endonucleases was probed by incubating polyplexes prepared with $\mathrm{PC}_{18}-\mathrm{CH}$ with DNaseI enzyme. This ability was tested at $\mathrm{N} / \mathrm{P}$ ratio 10 , and after DNaseI inactivation, polyplexes were degraded with chitosanase and lysozyme and pDNA integrity was checked by electrophoresis. Figure 4(d) shows the Ladder in column A, the free pDNA in column $\mathrm{B}$, the degradation of free pDNA in lane $\mathrm{C}$, and the $\mathrm{pDNA} / \mathrm{PC}_{18}-\mathrm{CH}$ nanoparticles in lane $\mathrm{D}$. After degradation with lysozyme and chitosanase, the release of pDNA without adding DNaseI is shown in lane E. After incubation with DNase I followed by degradation with lysozyme and chitosanase, the intact pDNA appears in lanes G (2.5 U DNaseI) and I (DNaseI 5U). Therefore, the NPs obtained with $\mathrm{PC}_{18}-\mathrm{CH}$ provided the necessary protection at $\mathrm{N} / \mathrm{P}=10$.

\subsection{Toxicity of derivatives and polyplexes}

In general, the cytotoxicity of cationic polymers depends on several factors and flexible macromolecules are expected to bind more efficiently to cell membranes than the 

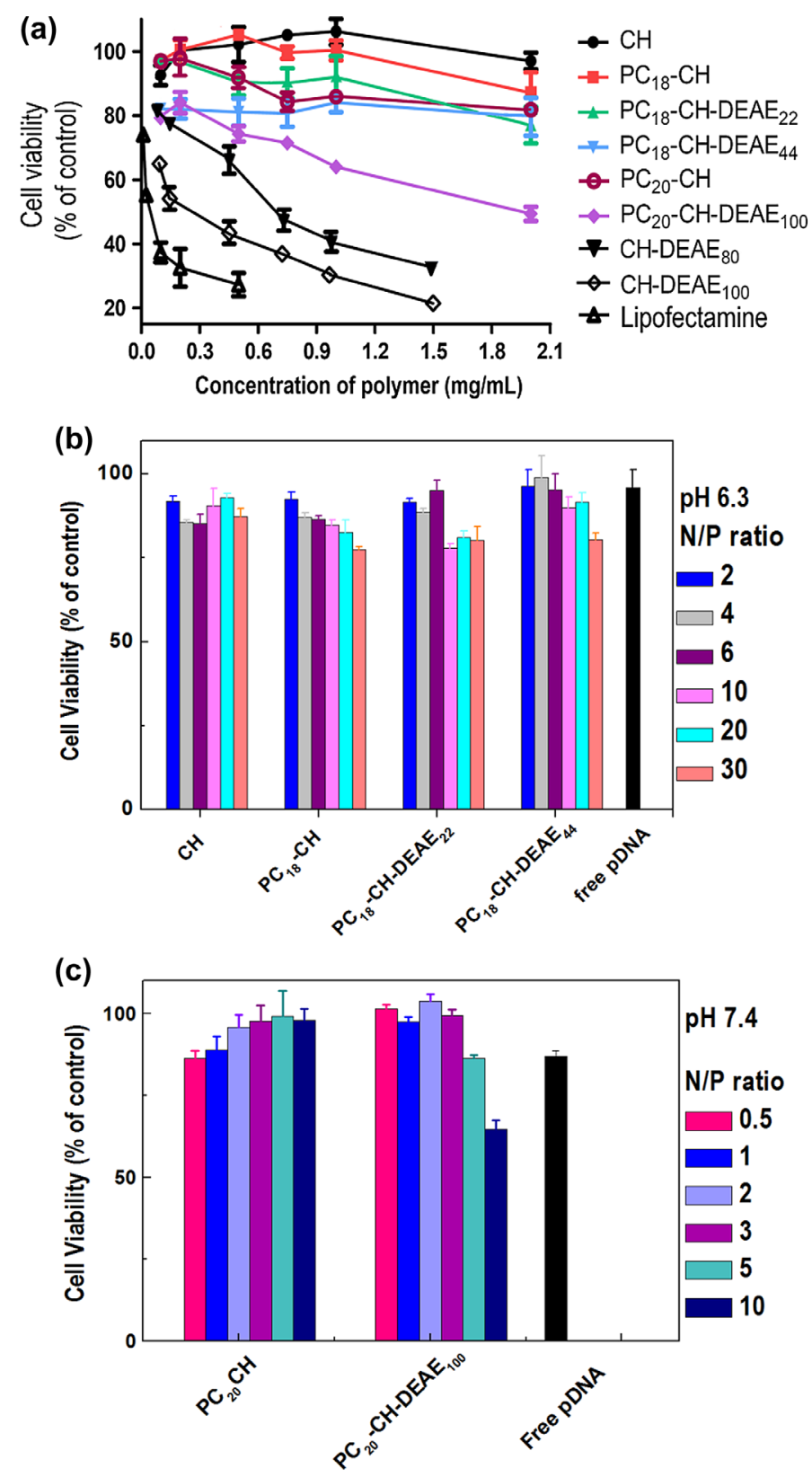

Figure 5. (a) Cytotoxicity of the polymers at various concentrations in HeLa cells; (b,c) Cytotoxicity induced by polyplexes containing an equivalent amount of $5 \mathrm{ug}$ of pDNA at various N/P ratios. Note. The results were expressed as percentage of the control (100\%).

rigid macromolecules. Moreover, flexible polymers having positive charge densities may cause higher cytotoxic effects than those having lower charge densities.[40,41] However, some studies reported that macromolecules possessing tertiary amine groups exhibit lower toxicities than those with primary or secondary amine groups. $[42,43]$ The toxicity of chitosan and its derivatives were evaluated on HeLa cells in the presence of increasing 
concentration of the derivatives using the MTS assay and are shown in Figure 5(a). The cell viability remained above $80 \%$ up to $2 \mathrm{mg} / \mathrm{mL}$, except for $\mathrm{PC}_{20}-\mathrm{CH}-\mathrm{DEAE}_{100}$, whose viability was decreased to $49 \%$ at $0.6 \mathrm{mg} / \mathrm{mL}$. We have previously shown that, regardless of the level of PC incorporation, the derivatives containing these groups are nontoxic after $24 \mathrm{~h}$ of incubation with KB cells. [5] Therefore, it is clearly noted that the cytotoxicity of the derivatives increases with the degree of substitution by DEAE groups $\left(\mathrm{GS}_{\mathrm{DEAE}}\right)$, and the $\mathrm{CH}-\mathrm{DEAE}_{80}$ and $\mathrm{CH}-\mathrm{DEAE} 100$ were the more cytotoxic derivatives. This trend can be attributed to increasing positive charge densities; however, all derivatives were less cytotoxic than lipofectamine.

The cytotoxicity of the chitosan polymer has been reported to be comparable to its nanoparticles yielding similar IC50 values, however, it is attenuated by the increasing degrees of acetylation and it is not significantly affected by Mw. [44] As observed from Figure 5(a), the attaching of DEAE groups has an impact on the cytotoxicity of the derivatives, however, the formation of the polyplexes partially neutralizes the positive charges and an N/P ratio-dependence is expected. For $\mathrm{N} / \mathrm{P}<6$ the cell viability in the presence of the polyplexes remained around $90 \%$ (Figure 5(b) and (c)); however, for N/P $>6$ the cell viability decreased to around $80 \%$, which can be attributed to the excess of polycations. This excess may increase the toxicity in two ways: first providing more positive zeta potentials (Figure 3(b) and Figure S3, Supplementary Material) and accordingly higher cytotoxicities to polyplexes, second by increasing the amount of unbound polycations chains in solution, which in turn may increase the cytotoxicity.[45] The polyplexes prepared with derivatives $\mathrm{CH}-\mathrm{DEAE}_{80}$ and CH-DEAE ${ }_{100}$ followed the same trend observed for $\mathrm{PC}_{20}-\mathrm{CH}-\mathrm{DEAE}{ }_{100}$ and the cell viability remained above $80 \%$ for $\mathrm{N} / \mathrm{P}$ ratios smaller than 3.0 .

\subsection{In vitro transfection activity of pDNA polyplexes}

The transfection efficiencies were evaluated at $\mathrm{pH} 6.3$ and/or 7.4 and exhibited strong dependence on the polycation structure and accordingly to $\mathrm{pH}$ and $\mathrm{N} / \mathrm{P}$ ratio as well. At pH 6.3 deacetylated chitosan $(\mathrm{CH})$ exhibited significant $\beta$-gal expressions only for $\mathrm{N} / \mathrm{P}$ ratios 10 and 20 (Figure 6(a)). At an N/P ratio of 20 the transfection efficiency was 20 -fold lower than that obtained at N/P 10, what may be attributed to the excess of chitosan. Recent studies reported that the excess of chitosan during the formulation of nanoparticles play an important role for transfection efficiency, [46] and the delivery is mainly controlled by the strength of interaction between chitosan and DNA, hence, the decreased efficiency at $\mathrm{N} / \mathrm{P}$ ratio 20 indicates that nanoparticles are excessively stable.[13] Moreover, at N/P 10 the transfection efficiency mediated by $\mathrm{CH}$ polyplexes was nearly fivefold smaller than that exhibited by lipofectamine (Figure 6(a)). For N/P ratios smaller than 10, transfection mediated by $\mathrm{CH}$ nanoparticles were insignificant, which may be partially attributed to the lower zeta potentials, which can decrease the cell uptake.[44]

As can be seen from Figure 6, the transfection efficiency mediated by polyplexes prepared with $\mathrm{PC}_{18}-\mathrm{CH}$ increases with $\mathrm{N} / \mathrm{P}$, reaching a maximum at $\mathrm{N} / \mathrm{P} 10$ and tending to decrease for higher $\mathrm{N} / \mathrm{P}$ ratios. This result correlates well with zeta potential measurements, which were positive only for $\mathrm{N} / \mathrm{P}$ ratios higher than 4.0, and reached a maximum of $+15 \mathrm{mV}$ at N/P 10 (Figure 3(b)). Above N/P 10 the zeta potential remains constant, which may indicate that either the excess of polycation is free in solution or weakly associated with the nanoparticle surface. Therefore, in spite of the positive zeta potentials exhibited by $\mathrm{PC} 18-\mathrm{CH}$ 
(a)

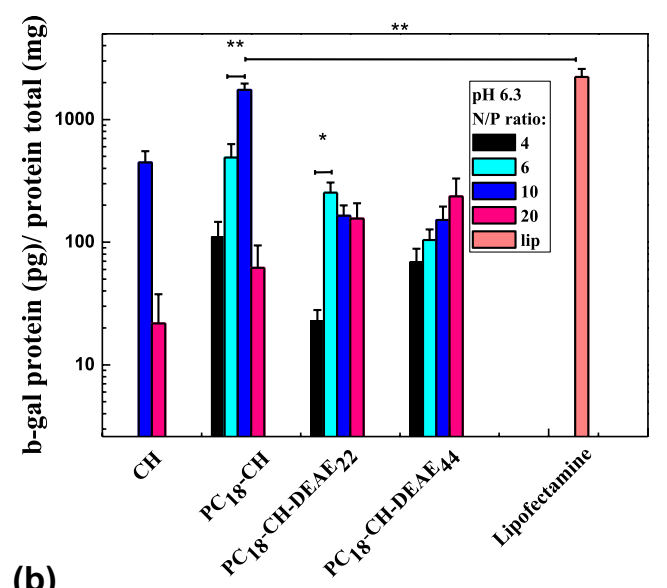

(b)

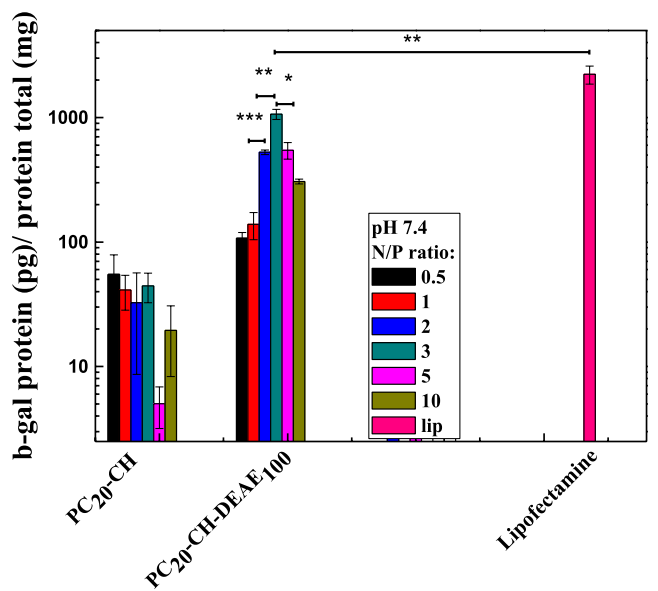

(c)

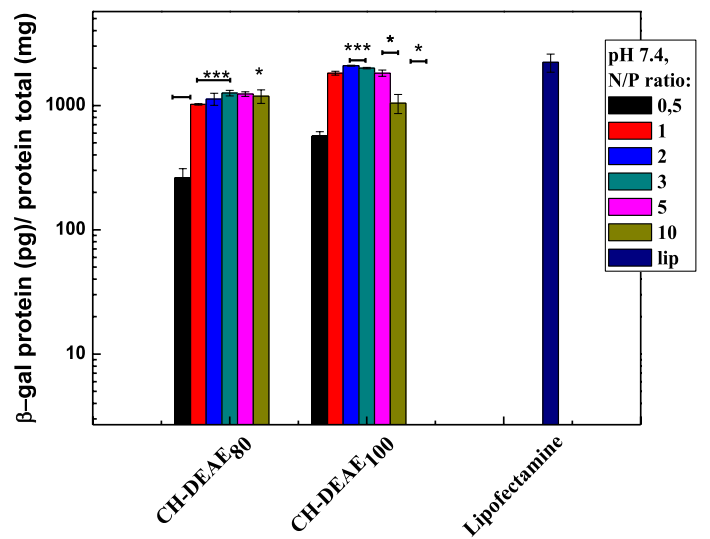

Figure 6. Transfection efficiency of nanoparticles prepared with (a) $\mathrm{CH}, \mathrm{PC}_{18}-\mathrm{CH}, \mathrm{PC}_{18}-\mathrm{CH}_{-}-\mathrm{DEAE}_{22}$ and $\mathrm{PC}_{18}-\mathrm{CH}-\mathrm{DEAE}_{44}$ at pH 6.3, ( $\beta$-gal protein /total protein); ${ }^{*} p<0.05$ e ${ }^{* *} p<0.01$. (b) $\mathrm{PC}_{20}-\mathrm{CH}, \mathrm{PC}_{20}-\mathrm{CH}-$ $\mathrm{DEAE}_{100}$ at $\mathrm{pH} 7.4$; $^{*} p<0.05$; ${ }^{* *} p<0.01$; ${ }^{* * *} p<0.005$. (c) CH-DEAE 80 and CH-DEAE 100 at $p H 7.4{ }^{*} p<0.05$; ${ }^{* *} p<0.01$; ${ }^{* * *} p<0.005$. 
polyplexes at N/P 20, the excess of polycation decreased the delivery into the cytosol. The transfection efficiency mediated by $\mathrm{PC}_{18}-\mathrm{CH}$ was nearly fourfold higher than that mediated by $\mathrm{CH}$ and is comparable to the commercial lipid lipofectamine, proving that the grafting with PC groups provides benefits to transfection process. This improvement may be attributed to the higher zeta potentials, moreover, the hydrophilicity of the PC group provides smaller sizes to polyplexes, which in turn may facilitate the cell uptake and the disassembling of polyplexes into the cytosol (Figure 3(a) and (c)).

On the contrary, the higher molecular weight derivative $\mathrm{PC}_{20}-\mathrm{CH}(\mathrm{Mw} 242 \mathrm{kDa})$ did not show the same efficiency (Figure 6(c)), which may be due to stronger interactions with polycations chains. Although unexpected, at $\mathrm{pH} 6.3$ the polyplexes prepared with $\mathrm{PC}_{18}-\mathrm{CH}$ $\mathrm{DEAE}_{22}(\mathrm{Mw} 29 \mathrm{kDa})$ and $\mathrm{PC}_{18}-\mathrm{CH}-\mathrm{DEAE}_{44}(\mathrm{Mw} 32 \mathrm{kDa})$ were not more efficient than $\mathrm{CH}$. This result may be rationalized by taking into account that the attaching of DEAE groups increases the ionization degree of the derivatives enhancing the strength of interaction between pDNA and the polycations.

At $\mathrm{pH}$ 7.4, beta-gal expression was not detected with both $\mathrm{PC}_{18}-\mathrm{CH}-\mathrm{DEAE}_{22}$ and $\mathrm{PC}_{18}{ }^{-}$ $\mathrm{CH}-\mathrm{DEAE}_{44}$ polyplexes. As observed in Figure S3(b) (Supplementary material), at pH 7.4 the zeta potential for both polyplexes were drastically reduced, which in turn decreases their binding to negatively charged cell membranes and subsequent uptake.

At $\mathrm{pH}$ 7.4, only polyplexes from $\mathrm{PC}_{20}-\mathrm{CH}$ and $\mathrm{PC}_{20}-\mathrm{CH}-\mathrm{DEAE}_{100}$ were able to mediate significant expression of $\beta$-gal. Overall, cell uptake is more efficient for chitosan nanoparticles prepared at $\mathrm{pH}$ values less than 7.0, due to their higher zeta potentials and smaller nanoparticles sizes.[36] Increasing $\mathrm{pH}$ values have an important impact on the transfection efficiency of chitosan nanoparticles and it has been shown that gene expression of nanoparticles prepared with chitosan oligomers decreases drastically for $\mathrm{pH}>7.2$.[16] Figure 6(b) and (c) show, respectively, the transfection efficiencies mediated by $\mathrm{PC}_{20}-\mathrm{CH}$ DEAE $_{100} \mathrm{CH}_{-} \mathrm{DEAE}_{80}$ and CH-DEAE ${ }_{100}$. Polyplexes of $\mathrm{PC}_{20}-\mathrm{CH}-\mathrm{DEAE}{ }_{100}$ mediated a level of $\beta$-gal expression $24 \times$ higher than those prepared with $\mathrm{PC}_{20}-\mathrm{CH}$, moreover, polyplexes of $\mathrm{CH}-\mathrm{DEAE}_{80}$ and $\mathrm{CH}-\mathrm{DEAE}_{100}$ provided transfection efficiencies comparable to lipofectamine. These improved efficiencies may be partially attributed to the higher zeta potentials, which reached values around $+10 \mathrm{mV}$ for $\mathrm{PC}_{20}-\mathrm{CH}-\mathrm{DEAE}_{100}$ (Figure S3(b), Supplementary material). The same interpretation may be applied to polyplexes prepared with $\mathrm{CH}-\mathrm{DEAE}_{80}$ and $\mathrm{CH}-\mathrm{DEAE}_{100}$, which exhibited the higher transfection efficiencies in the N/P range from 2.0 to 5.0 (Figure 6(c)) owing zeta potentials values around +10 to $+15 \mathrm{mV}$ (Figure S4(b), Supplementary material). On the other hand, polyplexes prepared at pH 5.0 exhibited very low transfection efficiencies, attributed to stronger DNApolycations interactions and the higher zeta potentials, which decrease the cells viability and the transfection process. [35]

\subsection{In vitro gene silencing of PC18-siRNA polyplexes}

Based on the results of the previous section, we selected $\mathrm{PC}_{18}-\mathrm{CH}$ derivative, which exhibited the best transfection efficiency compared to chitosan to investigate the gene silencing efficiency of $\mathrm{PC}_{18}-\mathrm{CH}$-siRNA complexes. The complexes were prepared at $\mathrm{pH} 6.3$ and their size and zeta potentials were checked and compared to those obtained with chitosan. It has been documented that complexation of siRNA molecules by chitosan is largely dependent on $\mathrm{Mw}$ and the range of $10-80 \mathrm{kDa}$ has been indicated as suitable to obtain polyplexes around 
(a)

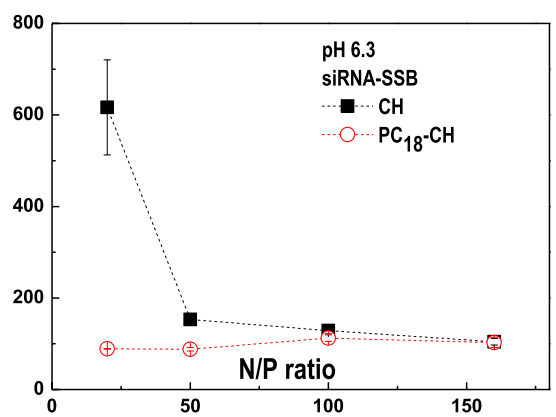

(b)

pH 6.3
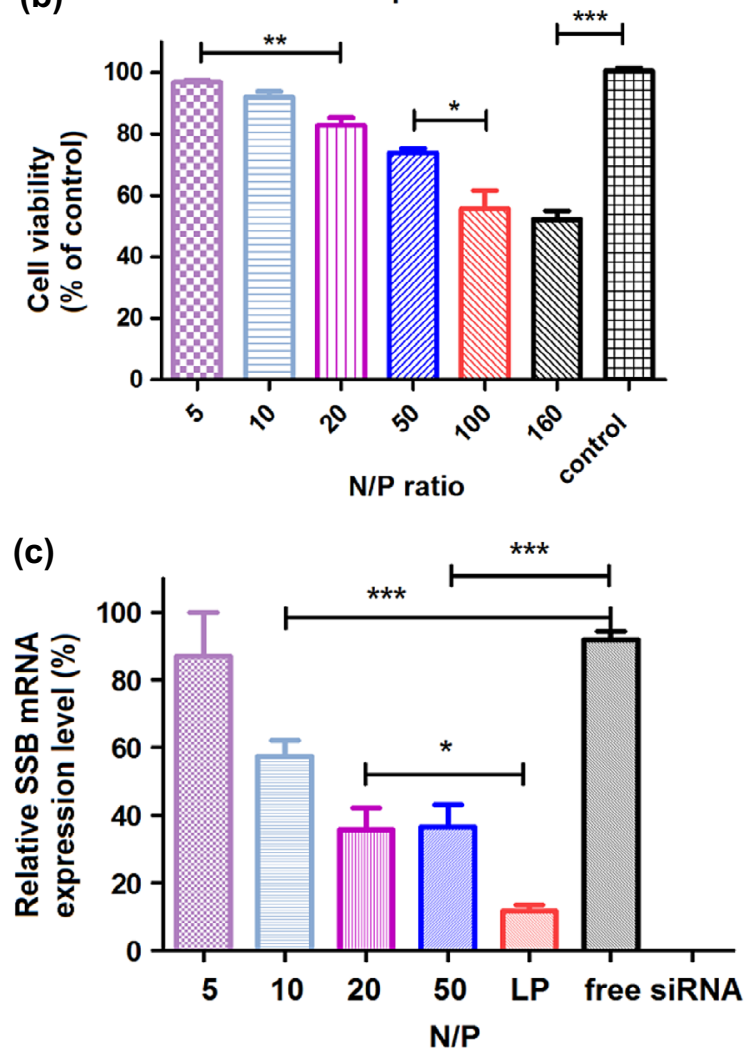

Figure 7. (a) Polyplexes size, (b) cell viability, and (c) in vitro transfection efficiency of free siRNA-SSB or $\mathrm{PC}_{18}-\mathrm{CH}$-siRNA complexes containing an equivalent of $5 \mu \mathrm{g}$ of siRNA SSB incubated with (A) HeLa cells. Notes. SSB gene expression is measured with real-time RT-PCR and compared with untreated cells, which are considered as $100 \% ; \mathrm{LP}=$ Lipofectamine $^{\circ}$. Statistical significance was assessed by the unpaired Student's $t$-test, ${ }^{*} p<0.05{ }^{* * *} p<0.005$.

100-300 nm.[47] The chitosan sample use in this work $(29 \mathrm{kDa})$ formed small complexes around $100-150 \mathrm{~nm}$ only for high N/P ratios (N/P $>40$ ), which is an expected result, taking into account its low ionization degree at this $\mathrm{pH}(\alpha \sim 0.5)$. Moreover, the high $\mathrm{N} / \mathrm{P}$ value can also be credited to the weaker interaction of chitosan with siRNA, which is a much smaller molecule compared to pDNA; however, the result is similar to others reported earlier by us 
[32] and other authors [48] (Figure 7(a)). On the other hand, $\mathrm{PC}_{18}-\mathrm{CH}$ formed complexes around $100 \mathrm{~nm}$ at $\mathrm{N} / \mathrm{P}>20$ with zeta potentials of $+19 \mathrm{mV}$ at $\mathrm{N} / \mathrm{P}$ ratio 20. The toxicity of the $\mathrm{PC}_{18}-\mathrm{CH}$-siRNASSB complexes were also evaluated on HeLa cells and as can be seen from Figure 7(b), cell viability remained around to $80-90 \%$ up to N/P ratio 20 , which is similar to those reported by chitosan.[7,32]

The silencing efficiency was evaluated for complexes prepared at increasing N/P ratios and compared to Lipofectamine as a positive control (Figure 7(c)). The silencing efficiency increased with N/P ratio blocking 43 and $64 \%$ of mRNA for N/P ratios of 10 and 20, respectively. At N/P 50 no further improvement was achieved regarding that obtained with N/P 20, and although unexpected, one can speculate that the requirement of an excess of polycation to provide the needed stability to polyplexes, may conversely delay the intracellular dissociation. When compared to our previous work on chitosan of similar Mw, this derivative allowed obtaining polyplexes having improved stabilities and superior knockdown efficiency than those exhibited by chitosans of similar MW.[32]

\section{Conclusions}

Our data showed that the obtained derivatives may exhibit distinct benefits for gene delivery depending on the degree of substitution. The attaching of PC groups converts primary amines into secondary amines, a transformation that preserves the polyelectrolyte properties of native chitosan and facilitates the association with pDNA. In vitro transfection studies with nanoparticles prepared at $\mathrm{pH} 6.3$ showed that substitution of the $\mathrm{PC}-\mathrm{CH}$ derivative by DEAE groups strengthens the interaction with pDNA and only the derivative PC-CH of low $\mathrm{Mw}$ was able to mediate transfection efficiency comparable to lipofectamine. In vitro studies performed with nanoparticles prepared at $\mathrm{pH} 7.4$ showed that, by increasing $\mathrm{pH}$, nanoparticles still preserve their positive zeta potentials, providing a more effective cell binding of the complexes, thus promoting cellular uptake. Moreover, the preparation of nanoparticles at $\mathrm{pH} 7.4$ weakens the interaction with pDNA and the most effective carriers were those having high DEAE contents $\left(\mathrm{PC}_{20}-\mathrm{CH}-\mathrm{DEAE}_{100}, \mathrm{CH}-\mathrm{DEAE} \mathrm{E}_{80}, \mathrm{CH}-\mathrm{DEAE}_{100}\right)$ that exhibited smaller nanoparticle sizes and higher colloidal stabilities. The PC-CH derivative of low molecular formed complexes with improved properties compared to chitosan, exhibiting ability to mediate in vitro knockdown with minimal cytotoxicity. In conclusion, polyplexes prepared with derivatives containing PC and/or DEAE groups may be promising gene delivery vehicles, and further adjustments in composition and molecular weight may confer to these derivatives potential for in vivo gene therapy.

\section{Disclosure statement}

No potential conflict of interest was reported by the authors.

\section{Funding}

This work was supported by the Fundação de Amparo à Pesquisa do Estado de São Paulo [grant number 2011/13960-0], [grant number 2010/09651-6]; the Conselho Nacional de Desenvolvimento Científico e Tecnológico [grant number 407499/2013-0]. 


\section{References}

[1] Morille M, Passirani C, Vonarbourg A, et al. Progress in developing cationic vectors for nonviral systemic gene therapy against cancer. Biomaterials. 2008;29:3477-3496.

[2] Miyata K, Nishiyama N, Kataoka K. Rational design of smart supramolecular assemblies for gene delivery: chemical challenges in the creation of artificial viruses. Chem. Soc. Rev. 2012;41:2562-2574.

[3] Danielsen S, Vårum KM, Stokke BT. Structural analysis of chitosan mediated DNA condensation by AFM: influence of chitosan molecular parameters. Biomacromolecules. 2004;5:928-936.

[4] Lin X, Ishihara K. Water-soluble polymers bearing phosphorylcholine group and other zwitterionic groups for carrying DNA derivatives. J. Biomater. Sci., Polym. Ed. 2014;25:14611478.

[5] Tiera MJ, Qiu XP, Bechaouch S, et al. Synthesis and characterization of phosphorylcholinesubstituted chitosans soluble in physiological pH conditions. Biomacromolecules. 2006;7:31513156.

[6] Liu W, Sun S, Cao Z, et al. An investigation on the physicochemical properties of chitosan/DNA polyelectrolyte complexes. Biomaterials. 2005;26:2705-2711.

[7] Liu X, Howard KA, Dong M, et al. The influence of polymeric properties on chitosan/siRNA nanoparticle formulation and gene silencing. Biomaterials. 2007;28:1280-1288.

[8] Katas H, Alpar HO. Development and characterisation of chitosan nanoparticles for siRNA delivery. J. Controlled Release. 2006;115:216-225.

[9] Bagheri-Khoulenjani S, Taghizadeh SM, Mirzadeh H. An investigation on the short-term biodegradability of chitosan with various molecular weights and degrees of deacetylation. Carbohydr. Polym. 2009;78:773-778.

[10] VandeVord PJ, Matthew HW, DeSilva SP, et al. Evaluation of the biocompatibility of a chitosan scaffold in mice. J. Biomed. Mater. Res. 2002;59:585-590.

[11] Kedjarune-Leggat U, Supaprutsakul C, Chotigeat W. Ultrasound treatment increases transfection efficiency of low molecular weight chitosan in fibroblasts but not in kb cells. PLoS One. 2014;9:e92076.

[12] Sato T, Ishii T, Okahata Y. In vitro gene delivery mediated by chitosan. Effect of $\mathrm{pH}$, serum, and molecular mass of chitosan on the transfection efficiency. Biomaterials. 2001;22:2075-2080.

[13] Strand SP, Lelu S, Reitan NK, et al. Molecular design of chitosan gene delivery systems with an optimized balance between polyplex stability and polyplex unpacking. Biomaterials. 2010;31:975-987.

[14] Du L, Gao Y, Yang H, et al. Hydroxyethyl-functionalized ultrasmall chitosan nanoparticles as a gene delivery carrier. RSC Adv. 2013;3:14791-14797.

[15] Morris VB, Neethu S, Abraham TE, et al. Studies on the condensation of depolymerized chitosans with DNA for preparing chitosan-DNA nanoparticles for gene delivery applications. J. Biomed. Mater. Res. B. 2009;89:282-292.

[16] Strand SP, Issa MM, Christensen BE, et al. Tailoring of chitosans for gene delivery: novel self-branched glycosylated chitosan oligomers with improved functional properties. Biomacromolecules. 2008;9:3268-3276.

[17] He C, Hu Y, Yin L, et al. Effects of particle size and surface charge on cellular uptake and biodistribution of polymeric nanoparticles. Biomaterials. 2010;31:3657-3666.

[18] Saranya N, Moorthi A, Saravanan S, et al. Chitosan and its derivatives for gene delivery. Int. J. Biol. Macromol. 2011;48:234-238.

[19] Prabha S, Zhou W-Z, Panyam J, et al. Size-dependency of nanoparticle-mediated gene transfection: studies with fractionated nanoparticles. Int. J. Pharm. 2002;244:105-115.

[20] Köping-Höggård M, Vårum KM, Issa M, et al. Improved chitosan-mediated gene delivery based on easily dissociated chitosan polyplexes of highly defined chitosan oligomers. Gene Ther. 2004;11:1441-1452.

[21] Kiang T, Wen J, Lim HW, et al. The effect of the degree of chitosan deacetylation on the efficiency of gene transfection. Biomaterials. 2004;25:5293-5301. 
[22] Verheul RJ, Amidi M, van der Wal S, et al. Synthesis, characterization and in vitro biological properties of O-methyl free N, N, N-trimethylated chitosan. Biomaterials. 2008;29:3642-3649.

[23] Chang KL, Higuchi Y, Kawakami S, et al. Efficient gene transfection by histidine-modified chitosan through enhancement of endosomal escape. Bioconjug. Chem. 2010;21:1087-1095.

[24] Jiang HL, Kwon JT, Kim EM, et al. Galactosylated poly(ethylene glycol)-chitosan-graftpolyethylenimine as a gene carrier for hepatocyte-targeting. J. Controlled Release. 2008;131:150157.

[25] Jiang HL, Kim YK, Lee SM, et al. Galactosylated chitosan-g-PEI/DNA complexes-loaded poly(organophosphazene) hydrogel as a hepatocyte targeting gene delivery system. Arch. Pharmacal Res. 2010;33:551-556.

[26] $\mathrm{Lu} \mathrm{B}, \mathrm{Xu} \mathrm{XD}$, Zhang X-Z, et al. Low molecular weight polyethylenimine grafted N-maleated chitosan for gene delivery: properties and in vitro transfection studies. Biomacromolecules. 2008;9:2594-2600.

[27] Gao Y, Xu ZH, Chen SW, et al. Arginine-chitosan/DNA self-assemble nanoparticles for gene delivery: In vitro characteristics and transfection efficiency. Int. J. Pharm.. 2008;359:241-246.

[28] Song LP, Zhu DW, Liu LX, et al. Evaluation of the coagulation properties of arginine-chitosan/ DNA nanoparticles. J. Biomed. Mater. Res. B. 2010;95:374-379.

[29] Ping Y, Liu CD, Tang GP, et al. Functionalization of chitosan via atom transfer radical polymerization for gene delivery. Adv. Funct. Mater. 2010;20:3106-3116.

[30] Case AH, Zaniquelli ME, Fernandes JC, et al. Physicochemical characterization of nanoparticles formed between DNA and phosphorylcholine substituted chitosans. J. Colloid Interface Sci.. 2009;336:125-133.

[31] Corsi K, Chellat F, Yahia L, et al. Mesenchymal stem cells, MG63 and HEK293 transfection using chitosan-DNA nanoparticles. Biomaterials. 2003;24:1255-1264.

[32] Fernandes JC, Qiu X, Winnik FM, et al. Low molecular weight chitosan conjugated with folate for siRNA delivery in vitro: optimization studies. Int. J. Nanomed. 2012;7:5833-5845.

[33] Liberda J, Trnka T, Sejbal J, et al. Preparation of biotinylated and FITC-labelled phosphorylcholine poly(acrylamide) derivatives and their application for protein ligand-binding studies. Int. J. Chem. 1999;53:528-532.

[34] Miyazawa K, Winnik FM. Solution properties of phosphorylcholine-based hydrophobically modified polybetaines in water and mixed solvents. Macromolecules. 2002;35:9536-9544.

[35] Oliveira FPP, Picola IPD, Shi Q, et al. Synthesis and evaluation of diethylethylamine-chitosan for gene delivery: composition effects on the in vitro transfection efficiency. Nanotechnology. 2013;24:55-101.

[36] Nimesh S, Thibault MM, Lavertu M, et al. Enhanced gene delivery mediated by low molecular weight chitosan/DNA complexes: effect of pH and serum. Mol. Biotechnol. 2010;46:182-196.

[37] Picola IPD, Busson KAN, Casé AH, et al. Effect of ionic strength solution on the stability of chitosan-DNA nanoparticles. J. Exp. Nanosci. 2013;8:539-552.

[38] Köping-Höggård M, Mel'nikova YS, Vårum KM, et al. Relationship between the physical shape and the efficiency of oligomeric chitosan as a gene delivery system in vitro and in vivo. J. Gene Med. 2003;5:130-141.

[39] Richardson SC, Kolbe HV, Duncan R. Potential of low molecular mass chitosan as a DNA delivery system: biocompatibility, body distribution and ability to complex and protect DNA. Int. J. Pharm. 1999;178:231-243.

[40] RYSER HJP. A membrane effect of basic polymers dependent on molecular size. Nature. 1967;215:934-936.

[41] Singh AK, Kasinath BS, Lewis EJ. Interaction of polycations with cell-surface negative charges of epithelial cells. BBA Protein Struct. Mol. Enzymol. 1992;1120:337-342.

[42] Ferruti P, Knobloch S, Ranucci E, et al. A novel chemical modification of poly-L-lysine reducing toxicity while preserving cationic properties. Proc. Int. Symp. Control. Rel. Bioact. Mater. 1997;24:45-46.

[43] Fischer D, Li Y, Ahlemeyer B, et al. In vitro cytotoxicity testing of polycations: influence of polymer structure on cell viability and hemolysis. Biomaterials. 2003;24:1121-1131. 
[44] Huang M, Fong CW, Khor E, et al. Transfection efficiency of chitosan vectors: effect of polymer molecular weight and degree of deacetylation. J. Controlled Release. 2005;106:391-406.

[45] Ma PL, Buschmann MD, Winnik FM. Complete physicochemical characterization of DNA/ chitosan complexes by multiple detection using asymmetrical flow field-flow fractionation. Anal. Chem. 2010;82:9636-9643.

[46] Thibault M, Astolfi M, Tran-Khanh N, et al. Excess polycation mediates efficient chitosan-based gene transfer by promoting lysosomal release of the polyplexes. Biomaterials. 2011;32:46394646.

[47] Ragelle H, Vandermeulen G, Préat V. Chitosan-based siRNA delivery systems. J. Controlled Release. 2013;172:207-218.

[48] Malmo J, Sørgård H, Vårum KM, et al. siRNA delivery with chitosan nanoparticles: molecular properties favoring efficient gene silencing. J. Controlled Release. 2012;158:261-268. 